\title{
DIALOGIC PEDAGOGICAL INNOVATION: CREATING LIBERATING LEARNING PRACTICES FOR FIRST YEAR UNIVERSITY STUDENTS
}

\author{
F. R. Mudehwe-Gonhovi* \\ e-mail: fmudehwegonhovi@ufh.ac.za \\ G. Galloway* \\ e-mail: ggalloway@ufh.ac.za
}

\section{G. Moyo*}

e-mail: gmoyo@ufh.ac.za

*Faculty of Education

University of Fort Hare

East London, South Africa

\section{ABSTRACT}

Liberatory and emancipatory thinking is shaped by a de-colonised approach to university teaching practices supported by literature on dialogic pedagogy. A theoretical framework for this article is shaped by the critical realism views of Archer's (2010) presented through the morphogenetic phases. At this particular university the grounding programme is a compulsory first year interdisciplinary module called Life, Knowledge and Action (LKA) aimed at promoting liberating practices through dialogic pedagogy. Interpretive and critical approaches were adopted, using mixed methods questionnaires, interviews and observations for data collection. The findings show that LKA was extremely liberating when students became contributors to knowledge creation. Students claimed/expressed their views stating that dialogue liberated them as it exposed them to diverse and alternative views and opinions. Considering the LKA aims the study recommends that the course be offered throughout undergraduate duration as it might be difficult to achieve all goals within a year.

Keywords: dialogue, South Africa, innovation, liberating, learning practices, university, decolonisation

\section{INTRODUCTION}

\section{Background and context}

The Grounding programme in the module LKA, is an initiative by the university's past Vice Chancellor, whereby his philosophical thinking was that of engaging students in greater dialogue during their $1^{\text {st }}$ year at this particular university, his vision was that of encapsulating a 
well-rounded, university student as a role model of society depicting good citizenship as a product of this particular institution (University of Fort Hare 2011). The concept transformed into a unique module called LKA introduced in year 2009 and is currently still a leading course at the institution for all $1^{\text {st }}$ year students.

Education should allow students together with facilitators/lecturers to negotiate on what they can accept as knowledge other than just take what is given without challenging the opinions. The architecture of the LKA has four levels which are the Umzi, the Ekhaya, the Village and the Jumboree. The Umzi was the first level with about six to eight students, followed by the Ekhaya with about thirty to forty-five students, the Village with ninety plus students then the Jamboree comprised of all students enrolled for the module (University of Fort Hare 2011).

Current university students have vociferously voiced their views on the emphasis of decolonising university teaching and learning content. This contributes strongly/richly to applying a more dialogical approach to collaborative teaching and learning. The emphasis of this statement is highlighted significantly by Skidmore (2000) who elaborates on the dialogic conceptualisation.

\section{LITERATURE REVIEW}

Skidmore (2000) cites Lyle who argues that "a dialogical conception of teaching and learning offers an emancipatory alternative to the traditional power-relationships of the classroom which tend to reproduce a pedagogy based on the transmission of pre-packaged knowledge". Skidmore (2000) argues that dialogism liberates the students as they are not bound by the rules of authoritative teaching and learning. Gomez, Racionero and Sordé (2010) elaborate further stating that, through language and action any person has the potential to "engage in dialogue", "create new knowledge and transform social context". Through dialogical engagement people become "transformative agents", their knowledge transforms contexts and lives; given the opportunity students become social agents bringing about innovative change to the teaching and learning context, namely that of collaborative engagement (Padrós et al. 2011). Freire a staunch contributor to critical and liberatory thinking suggests that:

"Any situation in which some men [students] prevent others from engaging in the process of inquiry is one of violence; ... to alienate humans from their own decision making is to change them into objects". (Freire 1970).

Influenced by the oppressive society he had lived in, he saw education being a true reflection of the society of the oppressor and the oppressed. In this case the teacher became the oppressor 
while the student was the oppressed. As Freire informs us that such forms of teaching is dehumanizing and hence Freire ignites our awareness that teaching and learning ought to create liberating learning practices.

For liberation in higher education to take place, Freire (1970) believed that the conventional roles of the oppressor/oppressed (teacher and student) had to be broken first. Dialogue, according to Freire (1970), is the concept that could bring emancipatory thinking to the education system where both the teacher and the student are considered as contributors to knowledge. Therefore, Freire contends that liberatory education lends itself to dialectical engagement, as stated below.

"Liberatory education works against the alienation of the student from their decision-making processes by posing problems in a dialectical setting. This changes the role of the student from an 'object' to a 'subject'. It is a process of authentic liberalization, of humanization. It fosters a setting that empowers participants to make their own decisions, name and explore issues, and challenge their place in the world". (Freire 1970).

Embracing dialogue in education, thus, gives university students a sense of responsibility in their studies as they will be aware that their input is also important in the knowledge development process. For example, the recent \#fees must fall situation arose out of the voices of students who felt that university management was not listening to and taking cognisance of their dire plea for a revised more decolonised education system.

In support of this Mercer (2000) asserts that facilitators/lecturers offer guidance to students towards critical thinking, which encourages students, facilitators and lecturers to unpack content through dialogical interaction. Critical thinking referring to "that mode of thinking - about any subject, content, or problem - in which the thinker improves the quality of his or her thinking by skilfully taking charge of the structures inherent in thinking and imposing intellectual standards upon them" (Paul and Elder 2008). Alexander (2004) advocates for dialogic instruction in which interaction is genuinely "reciprocal and cumulative" as opposed to the question and answer lecture hall discourse which has been termed "interactive teaching". Initially Skidmore (2000) has indicated that there is more value in the genuine reciprocal dialogue which develops the students' reflective capacity. This created space for reflection through dialogue liberates the students during lectures. This means that the learning environment becomes an active and interactive collaborative learning space where the breadth and depth of knowledge is experienced and whereby liberating and emancipatory thinking emanates from the contributions of students.

On the flip side, Tochon (1998) argues that there are possibilities of negative 
interdependence amongst the students as a result of some borrowing of ideas from the peers. He further states that in as much as there are cognitive benefits of these collaborative approaches to learning lecturers need to monitor closely the relations between students to ensure that they do not engage in constant conflict. Flecha (2000) contends that positive collaborative learning works better when students have the same learning goals, outcomes and motivating factor.

The purpose of this study was to investigate how dialogic pedagogical innovation within a university grounding programme created liberating practices for first year students. To explore this, the research question is: How does dialogic pedagogical innovation create liberating learning practices for first year university students?

\section{Dialogic pedagogy - conceptual understanding}

One needs to ask the question: Where did dialogic pedagogy come from and how do we conceptualise and develop an understanding of and for dialogic pedagogy at university level. Dialogic pedagogy is a theme that has its origins in the Vygotskian view of "mediated learning" (Maybin 2003), where subtle interaction takes place between people which stresses the communal building of knowledge through sorting of ideas. It seeks to go beyond presented information (Presseisen and KoZulin 1992).

Bakhtin (1981) was interested in utterances as they respond to preceding utterances as well as anticipating future responses. Similarly, Cook (1991) argues, "participants influence one another in a conversation as they interrupt, ask for more information and adopt" ideas. This means that contextual discourse is identified by a series of utterances that are initiated and all the following participants respond to the shared ideas on a certain topic of discussion and the generation of new topics as a result of thinking processes that take place as the conversations or discussions progress. In the same vein of dialogic pedagogy, Bakhtin (1981; 1984) suggests that this approach focuses on how students and the facilitators/lecturers "co-construct knowledge" through classroom talk. Alexander (2006) expanded on Bakhtin's theory and suggests that dialogic pedagogy has positive results as it is reciprocal, collective, cumulative, supportive and purposeful as the facilitator/lecturer and students co-construct knowledge. In this dialogic approach, Nystrand, Gamoran, Kachur and Prendergast (1997) and Skidmore (2000) concur with Bakhtin's theory that co-constructed knowledge is liberating as shared knowledge unfolds. Nesari (2015) comments that dialogism allows conflict as different views are shared as opposed to a "universal truth". Nesari (2015) states that, "According to Bakhtin every human being likes to resist, confront and make personal meaning out of social interactions". This means there is competition as everyone seeks to convince others of their 
views.

Another author namely, Mcleod $(2007,2018)$ contends that dialogue does not only involve simple talk or sharing ideas; it is also structured, a process that leads to new insights and deep knowledge and understanding leading to better practice. It aims at going beyond participants' initial stages of knowledge and belief. Dialogic teaching, according to Alexander $(2010,1)$, is defined as an approach to teaching which "harnesses the power of talk to stimulate and extend pupils' thinking and advance their learning and understanding". It is this type of stimulation that is required for the development/learning where students are thus forced to think rather than just waiting to be fed with information by the educator.

Dialogue, according to Flecha (2000), is egalitarian; this is true only when the contributions are treated with equal importance regardless of the position held by the contributors. This brings to mind that (in recent years) the need for interactive collaboration and dialogue in university classes was becoming the modus operandi that students favoured hence taking on a more liberating and emancipatory form of knowledge contribution and knowledge empowerment attuned to a more critical theoretical approach to the pedagogy of university teaching and learning. Freireian stated that students no longer favoured the authoritarian approach to knowledge but were leaning towards a two-way engagement of shared discipline content knowledge as a co-constructed approach to learning practices removed from the "banking approach" whereby the oppressor deposits knowledge and the students passively receive knowledge.

Shor and Freire (1987) argue that dialogue is a mutual learning process that discards lecturing where lecturers talk silencing and distances students. According to Shor and Freire (1987) liberating dialogue should not be viewed as a technique used by lecturers to become close to students but rather as part of the nature of human beings. He defines dialogue as a moment where humans meet to reflect on their reality as they make and remake it. The facilitators/lecturers responsibility is to pose "critical problems for inquiry". This then creates space for participation in discussion, contributing to debates and solving problems collaboratively.

Rule (2011) argues that the point is not to win the argument but to learn from one another and discover the truth together about the issue under discussion. Therefore, whether the dialogue happens between facilitator/lecturer and students or among peers there should always be willingness to learn from one another. Freire (2005) contends that in this method all are able to learn and all are able to teach as all contributions help in the development of knowledge. In other words, collective knowledge adds richness to understanding and critical thinking. As cited by Skidmore (2000), Nystrand "calls dialogically-organised instruction characterised by the 
following: the use of authentic questions, where the answer is not pre-specified; uptake, the incorporation of previous answers into subsequent questions; and high-level evaluation". This means there is interaction taking place as students question opinions and their ideas used to build discussion as opposed to the traditional way of teaching and learning where it is teacher centred. These interactions therefore result in change as suggested by Archer in the morphogenetic cycle. This will be explained in the next section.

\section{The morphogenetic phases}

Morphogenesis argues that social structure is constantly going through changes as a result of both intended and unintended consequences due to human interaction and activities (Archer 2010). The agents are bound to gain from one another and no one has authority on what is to be learnt or accepted as all are equal contributors.

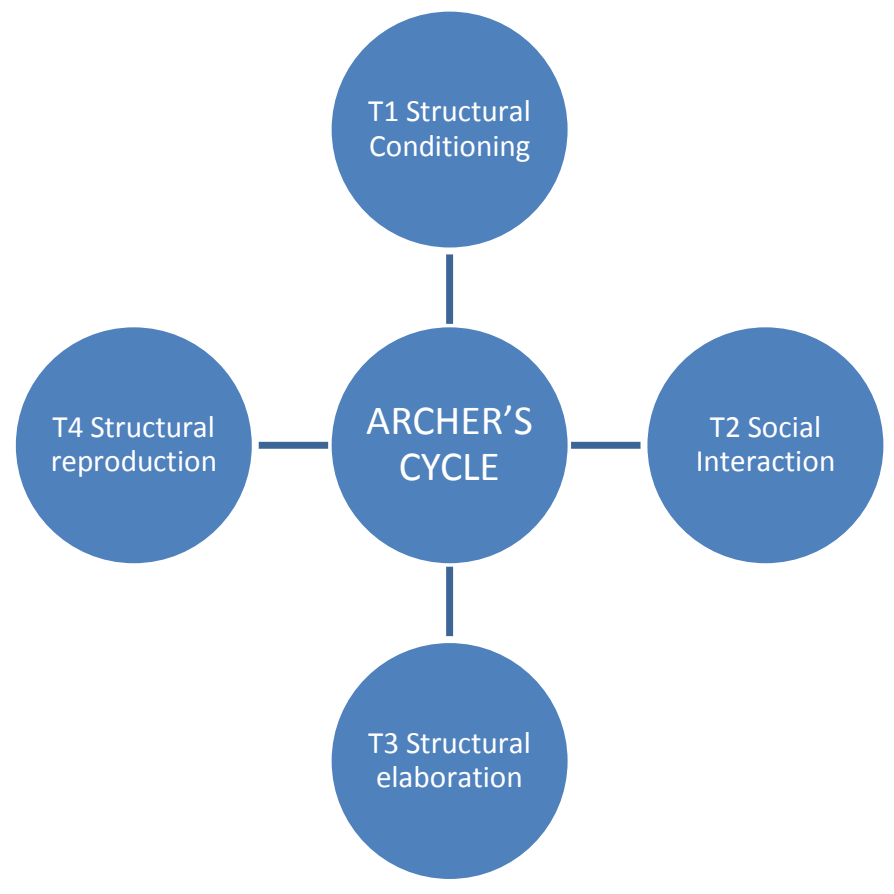

Figure 1: The morphogenesis of structure (adapted from Archer 1995)-cyclical structure

The first phase (T1) of the morphogenetic cycle is the structural conditioning from prior experiences (Archer 2010). Further interactions then have an effect on the participants involved and these vary from one group to the other. It is of importance to highlight the fact that causal influences operate within the time dimension. As Archer states, "It takes time to change any structural property and that period represents one of the constraints for some groups at least" 
(1995, 75). According to Archer (2010), the second phase is the social interaction phase with agents exerting causal influences on one another. Between Phase 2 (T2) and phase 3 (T3) the two "independent influences" namely "temporal" and "directional" have the potential to either accelerate or thwart change. Agency will result in elaboration of the original structures while non-agency will result in the production of the original structure. With the directional influences agency can re-define the contents or meaning of concepts, theories, designs or other cultural schemas, thus affecting the structural elaboration. In the third phase the social interactions result in the development of new structures (elaboration) or it just repeats the old ones (reproduction). Elaboration shows that change has taken place while reproduction means there is no change but the production of the original structure.

\section{METHODOLOGY}

For this research, the use of mixed methods provides a pattern best suited to the phenomenon being studied. This paradigm fits the phenomenon under study as the students were interpreting and understanding their experiences as $1^{\text {st }}$ year university students bringing with them contextual pedagogies and social understandings. Before engaging in the conceptualising of a mixed method approach an explanation what a "paradigm" is. A paradigm is a cluster of beliefs and practices associated with a particular worldview about how scientific practice should take place (Becker and Bryman 2004, 401). It also refers to philosophical frameworks that guide the researchers in carrying out their research (Gibbons and Sanderson 2002). Paradigms are also viewed as the all-encompassing systems of interrelated practices and thinking.

The interpretivist research paradigm strives to understand and describe human nature. In this paradigm, knowledge is subjective and idiographic because what counts as truth is context dependent, unlike natural sciences that look for consistencies in data in order to deduce laws (nomothetic) (Gray 2005). There are, therefore, multiple realities, which are constructed (Denzin and Lincoln 2003). Thus, data gathering is achieved through interviews, participant observation, diaries, pictures, and documents. However, this study infuses with a critical theoretical approach as critical theory, leads our thinking into emancipatory and liberating notions of innovative dialogic pedagogy. The blending of these two paradigms will strengthen this study.

\section{Research design}

For the purposes of this study the researcher used the survey and case study research design. The research design serve to "plan, structure and execute" the research in a bid to maximize the "validity of the findings" (Mouton 1996, 175). Validating the findings is absolutely essential to 
determine what the $21^{\text {st }}$ century $1^{\text {st }}$ year student regards as dialogic pedagogy.

\section{Sampling and data collection}

The sample size for this study was $155(15.06 \%)$ students for the year 2013 at this university in the Eastern Cape from a total of 1029 registered students. The university has 3 campuses whereby the study was conducted at on two campuses of the university named/coded as campus A and campus B. Bearing in mind that LKA is a particular module designed for this particular university to develop engagement with $1^{\text {st }}$ university students.

The instruments for data collection included interviews, observations and questionnaires carried out at the end of the second semester in 2013. The questionnaires included both qualitative and quantitative data; whereby the quantitative data analysis was designed to show the trends that existed within the grounding programme while the qualitative data analysis was designed to explain the emerging trends that emanated from the study. The analysis of the data seeks to investigate whether there was dialogue in the programme at the different levels of student meeting(s) namely the umzi, ekhaya and village levels and whether it brought change to the participants knowledge and thinking about university as a place for citizenship development, growth and dialogical contribution to student knowledge.

\section{FINDINGS}

This section will discuss findings from the interviews and questionnaires and the sub-headings refer to the themes that emanated from the interviews/questionnaires as stated by the students.

\section{Students who participated less at the beginning of the course improved over time}

The $1^{\text {st }}$ year students felt that some students improved in their participation over time. As one student commented, "I used to struggle to say my thoughts, through discussions with colleagues I was challenged as I saw people with not so good points but had confidence to share them. I therefore had my confidence boosted. Discussions helped me come out of my shell." This indicates how dialogue builds an environment that liberates the student, as facilitators played a role of motivating students who initially did not feel comfortable to share their views in a group initially. Another student stated that, "at first there is this tense environment in my ekhaya but the facilitator made sure that everyone is comfortable and everyone participates, he just motivates you to speak".

\section{Dialogue changed their way of thinking}


Everyone has their way of thinking influenced by their experiences and surroundings bringing with them literacies of context, culture and/or religion, in the past. Most students enrolled for LKA with their beliefs and understanding and the LKA experience made an impact on a great number of students.

\section{Cultural understanding(s)}

The students being from different cultural backgrounds would in no doubt have different beliefs and values; these would be as a result of different origins and ways of socialisation. It is these students, through dialogue, who had their ways of thinking modified. The ways they perceived things was changed due to the contributions that came from fellow students in a bid to negotiate towards a common understanding; "It changed the way I perceive things. It has opened my mind and now I have a new perspective on life." Co-creation of common understanding, built from a position of listening too, engaging with and reconceptualising an understanding of "the other" through dialogic pedagogy, "I gained a lot through participation and you tend to look at things in diff angles then that will be the way of learning".

\section{Dialogue changed students' interpersonal skills}

Dialogue is all about exchange of ideas, communication, interaction and discussion but it requires some level of expertise. According to the students, dialogue helped them to develop this kind of expertise drawing on Freireian theories and emancipatory thinking, which they lacked before enrolling for the course. Some students indicated that they can now communicate with people freely contributing to an emancipatory approach and interaction. This means that they now know how to carry out a conversation with ease developing; "It made me a person capable of interacting with people. It taught me to engage with people in society". Interpersonal skills as a human right showing the importance of dialogue and communicative engagement seen as a liberating strength amongst $1^{\text {st }}$ year university students. For some dialogue widened their ability to interact with other students and were able to make friends, "It made me know people and know them on a friendly and personal level”.

\section{Dialogue boosted self-esteem and confidence}

To conquer the world that we live in needs confident people. Life beyond university is more challenging as individuals have to get into different situations where only those with confidence can earn respect. It is the focus and aim of LKA to produce candidates ready for the life as a university citizen as well as prepared to take up their rightful place as good citizens after university in the corporate world. Students suggested that through discussions they received 
encouragement from peers which made them realise their potential thus boosting their selfesteem, "It made me confident. It helped me realise that everyone is important and has something to offer to the society. It built my self-esteem. It made me a confident person free to share my views without intimidation."

\section{Dialogue creates critical thinkers}

It is the LKA programme's aim to produce critical thinkers. Some students highlighted that dialogue broadened their mind-sets thus making them critical thinkers, "It made me a critical thinker and confident to present in front of people. Now I can engage critically. " It is when you become a critical thinker that you can "engage in constructive discussions". "It taught me how to engage in constructive discussions." Through discussions the students got to change their mind-sets as they received different views from group members. This helped them to be objective and to be able to look at things in a logical manner, "It broadened my mind-set. I broadly and logically think". Similarly, the interviewed students confirmed the suggestions that were raised in the questionnaires on students being made critical thinkers through discussions. One student said "It made me a critical person, also to be that person who doesn't think in one direction it broadened my thinking that when you see a situation you need to be critical about it'.

\section{Dialogue increased knowing more about life}

The theme of interest in knowing more about life is of interest in the sense that it prepares students for life after university; as stated by one of the students, LKA is not about academics but there is more to it in the sense that it takes you beyond academics and prepares you for real life situations in the society or at work places, "LKA produces students who can stand on their own, who can work hard and work as a group also keep students from doing wrong thing like taking drugs. Teach us how to live in a diverse democratic country like South Africa." This seems to confirm the LKA purpose. These students highlighted that dialogue helped them to see clearly the path that they would want their lives to take and understand significant issues of life, "I now know what to do with my life". Some students who came in arrogant became modest when they realised that there is no one who is immune to challenges of life. It is through this dialogue that students were equipped to deal with different life situations, "I am not arrogant anymore; I have learnt that what can happen to others, can also happen to me". Some students also suggested that students who were less interested in gaining knowledge about life, "I am now interested about knowing more about life", through dialogue they were now motivated to know more about life. This seems to imply that students can either develop interest in studying 
more about life outside prescribed university courses or engage in more discussions in social circles in a bid to acquire knowledge. These $1^{\text {st }}$ year contributions align with the purpose and aim of the LKA programme (University of Fort Hare 2011).

Through sharing of ideas, I developed a better understanding of significant issues in life, "It broadened my level of understanding of issues that are significant in life". This seems to imply that in life there are people who exert a lot of attention on the wrongs, ignoring those that are important and change of perception can only come through discussions as people share ideas and experiences. As a result of sharing views through discussions people tend to understand things differently and come out of the discussion with ideas or solutions as to how they can overcome or sail through certain challenges "I now know how to tackle situations presented and I have a different perspective of life".

\section{Dialogue created respectful people irrespective of differences}

In this sub-theme the students show an appreciation of the fact that people are different, have different ideologies, and different backgrounds, but regardless of these factors an individual's attitude towards others is of importance. The students highlighted that everyone is important in a society and they have got something to offer, "I have developed acceptance of people irrespective of their race or cultural background. It helped me realise that everyone is important and has something to offer to the society." Different as we are this student felt that there is no one who is immune to challenges; the only difference is how each individual deals with the challenges, "It has made me aware how different we are and yet similar in that we all face same challenges but it's how you apply yourself to the challenges".

Some of the $1^{\text {st }}$ year students enrolled for the programme confessed to having had negative thoughts about some of their group members and that it was only through interaction and discussions that they realised that their thoughts were misguided, "I now do not have negative thoughts about others, I used to have negative thoughts about girls in my Umzi”. On the other hand, some students suggested that they started valuing other people's views and that through these views they have been equipped with solutions that they feel could benefit the society, "I learnt to respect other people's views. I now value other people's ideas and am able to come up with solutions that benefit the society." In the same vein some students felt that contributions that were given by other students made their learning process easier as they made clearer the issues under discussion, "Views of other students helped me understand the topics we discussed". This is confirming that everyone can contribute valuable information in the society.

\section{DISCUSSION}


One of the findings is that LKA creates opportunities for dialogue and that it liberates $1^{\text {st }}$ year students ability to engage and contribute to conscious debates. The literature on dialogue shows that it has been agreed upon by a number of scholars that dialogue has a liberating effect on students. Lyle as cited by Skidmore (2000) states that dialogue is an emancipating alternative to the oppressive traditional relationships within the classroom. According to the author the students are faced with "pre-packed knowledge" in the traditional classroom unlike in the dialogic classroom setting. In the same vein Freire (1970) pointed out that the education system has been trapped in the "banking education" system where students are taken as receivers of information from the teachers. Freire (1970) suggested that the students occupied the position of the "oppressed" and the teacher the "oppressor". This setting did not encourage knowledge making which he believed came through construction and reconstructing of ideas by people involved in a dialogue. As argued by Freire (1970) these oppressors/oppressed roles assumed that the education system had to be broken down for transformation to take place. This therefore shows that liberation is transformation as students move from oppression to liberation. This transformation in students', thinking, attitude and approach emanates from dialogue as argued by Freire (1970). Hence the paradigmatic understanding of interpretivism and critical theory is appropriately presented through this study. As liberatory ways of teaching and learning is through dialogic pedagogy whereby students learn from peers and lecturers emancipate their ways of thinking about teaching by welcoming students' comments and dialogue into their lectures embracing a dialogical approach to teaching and learning.

Archer (2010) argues that the challenge is, when you are born into a structure you will always reproduce that ideology all the time. She argues that action plays an essential role in both the reproduction of the structure as well as the elaboration of the structure. Action is perpetual, agents will always experience the cycle of structural conditioning-social interactionsocial elaboration or social reproduction. Dialogical interaction in this case will always be playing an important role. It is the tool for either transformation or reproduction.

In terms of the articulation that the students are coming from a situation of deprivation to a university structure, to navigate around that structure students need to exercise agency. They need to think and take action to change the university structure, and hence the study argues that dialogue is one way that students can exercise agency. According to Archer's cycle, students when they interact they are being enabled to exercise agency in order to change the structure. Students come from a structure prior to university and into another structure, namely the university structure. The findings show that for most students the interaction resulted in elaboration as they came into the LKA programme in one state and by the end of the course they had experienced some form of transformation and liberation through airing their views that 
attributed to the change and interactions they were exposed to in the dialogical sessions of the programme.

The LKA programme aims to create critical thinkers through dialogue (University of Fort Hare 2011). In the period 2016-2017 the programme has replaced individual assignments by group assignments which are done through dialogue. This will enhance students' critical thinking skills (University of Fort Hare 2016). If people are not critical, they will just reproduce the structure that they were born into. When students engage in dialogue, they are being allowed to "name" the world and, according to Freire (1970), not someone else naming the world for them. This argument is similar to Archer's (2010) argument of structural elaboration. By structural elaboration Archer means the social interactions result in the development of new structures (elaboration) or it just repeats the old ones (reproduction).

Morphogenesis argues that, social structure is constantly going through changes as a result of both intended and unintended consequences due to human interaction and activities and evidence from the findings showed and revealed itself through extracts such as "It changed the way I viewed things. Now I have better understanding of things. It changed me because I was a person who had lack of confidence to speak to share my views with other people." Dialogue in LKA, as a grounding programme, therefore, gives the potential to change as the nature of the course is designed to meet 1 st year students at different levels of knowledge structures. It gives them the opportunity to go through the process in T1, T2 and T3 as presented by Archer (2010) meaning that at T1, T2 and T3 stages the change/liberation effectively takes place (see Figure 1). Dialogue gives the student the potential to liberate themselves from the deficit model where not much is expected from them.

The research shows evidence of critical theory in practice as liberation amongst students especially in the Umzi and the Ekhaya. Students suggested that they met to discuss as they shared information and opinions on different topics scheduled to be discussed following the study guide. Within the Ekhaya they had facilitators who just came in to support discussions and everyone in the class, including the facilitators, was part of the teaching and learning process. Students are set free from oppression if they take action if the education system embraces the dialogic approach to teaching and learning. Through dialogue students are welcomed as knowledge contributors as their contributions are used to influence the world. In the same vein of students contributing to their education Ngugi waThiong'o a renowned African intellectual recently went around South African universities calling on students to decolonise their education. He argued that change normally comes with the intervention of young people.

This study gives strong support to dialogue as a liberating tool. This suggests that the education system could benefit greatly by adopting and/or transforming its teaching and 
learning pedagogy into a more dialogic approach. Students were very much liberated as they got opportunities to share their ideas during dialogue engagements with each other.

The strength of LKA is that Knowledge was communally constructed by students and facilitators as well as lecturers. Evidence from the research shows that the students realised that people are important in knowledge construction. One needs to acknowledge that everyone can make a contribution in society for them to learn new things from others. There is willingness from one another and sharing of same ultimate goal for dialogue to benefit members/participants of the dialogue. However, as will be shown in the following sections, the level of liberation was different in all three grounding programme levels, the Umzi, Ekhaya and Village.

Students embraced the power of talk in order to liberate themselves. Through language and action any person has the potential to "engage in dialogue", "create new knowledge and transform social context" (Gómez, Racionero and Sordé 2010). By participating in dialogue people become "transformative agents" and their knowledge transforms contexts and lives. Given the opportunity, people as social agents bring huge changes (Padrós et al. 2011). During the discussions the students took responsibility knowingly or unknowingly to contribute and hence transform their lives and enhance their critical thinking skills. It should be noted that students argued that they were liberated when they were in the Umzi and the Ekhaya as opposed to the Village. The students stated that in the Umzi and Ekhaya they felt comfortable to engage as they had no one standing in an authority position during the sessions. The students identified each other as partners or friends which made it more comfortable to share their views without intimidation. This confirms the notion of naming the world for themselves Freire (1970). In the Umzi the students collaboratively developed knowledge without the interference from facilitators or lecturers. At this level that is where more dialogue took place and students suggested that they were challenging each other's thoughts as peers. At this stage the architecture created a platform that enables everyone in the group to exercise agency either voluntarily or involuntarily as it allocated marks for making a contribution within the group. A platform for new knowledge making was created for the students just as peers. At the Ekhaya, though, it had the potential to be affected by the authority dynamics as the abakwezeli (facilitators) were introduced at this stage to facilitate dialogue to transform the students and with the potential to transform the facilitators as well. At this level students and facilitators exercised agency together.

However, when it comes to the Village the programmes seems not to deal with the issues of authority. Evidence from the research, shows that, the students view the Village in the same way as the normal university lectures where the lecturer comes and gives a lecture while 
students are only receiving information. At this level, it appears that a conforming approach to autocracy of the lecturer manifested itself and hence stifled the communicative engagement with students a more structured colonial approach was employed. Even though some students highlighted that questions are asked within a Village session, the dialogue is at its minimal. The lecturer still assumes the authority position. Since the programme seeks to do away with the authority assumed by lecturers which seems not to be fulfilled, the study, therefore, suggests that the programme administrators might have to revisit the architecture and restructure and or maybe do away with the Village altogether. With the levels of power dynamics, it is difficult for the students to exercise agency. In the $21^{\text {st }}$ century it has become evident that stronger student communication through dialogue as experienced by the \#fees must fall in 2016, made a statement that student voices are to be heard as articulate citizens of society making a statement for reform in South African universities with the main focus on social justice and university access for all students (Gumede 2017). The power of the voice and the importance of dialogue in 2016 carrying over into 2017 is a strong message of the relevance of dialogic pedagogies, decolonised approach.

Students highlighted that the group at village level is too big to manage a smooth flow of dialogue. The second concern was the fact that the Village is too big; it takes a lot of time before the students settle down and, when they finally do, not everyone is paying attention to the proceedings of the class. Disruption due to large numbers is a problem in higher education. Students are often involved in dialogues with friends or just doing other activities besides the dialogue intended to happen in the session. Since the Village has a big number of participants expected to take part in the dialogue, the time allocated for the session does not suffice for all students to make contributions.

Findings from the analysis indicated that the dialogic pedagogical innovation created liberating learning practices in that students commented that, firstly, a platform was created for them to share their views during discussions. Evidence show that agential interactions were increased where there was no authority dynamics. Secondly, students said that they made contributions towards learning without fear of being judged. Thirdly, the students acknowledged that they were considered as equal contributors to knowledge. Lastly, they commented that through dialogic pedagogy transformation took place. These student contributions confirm the interpretive and critical paradigms framing this study.

Students indicated that dialogue created better interpersonal skills and boosted their confidence in social circles as well as their studies. Dialogue made students informed people and made them interested in getting more information about life. Dialogue created critical thinkers and better writers. It also changed their way of perceiving things in life; also they 
developed respect for others through dialogue. Rautopuro and Vaisanen (2011) suggest that there is a dire need for universities to take student voices seriously aligning to $21^{\text {st }}$ century teaching and learning of universities. The LKA has taken into consideration this call of developing innovative programmes to better the standard of the university academically and came up with the unique programme that aims at taking care of the students' needs as a whole. They also argue that the university education needs to make people ready for life after graduation and develop students' lifetime learning skills. The LKA aims at doing this through dialogue which encourages critical thinking and motivates students to take responsibility for their learning.

The challenge presented by the LKA might be that, following this, can all these things be achieved in only one year? The other challenge could be that students in first year are unsure of their studies such that they might miss the teachings of the LKA and the results of the programme might not be fully accomplished. The fact that the course is made compulsory can be problematic as well, as students end up attending the sessions just for obtaining marks so that they will be able to graduate at the end. LKA ought to form the foundation for creating "space" throughout the disciplines' programmes and enhance the emancipatory notion of "student voices" in the $21^{\text {st }}$ century as knowledge contributors through dialogical pedagogical innovation

University education should prepare students to contribute to their working life the society. LKA running only for a year can be problematic in the sense that most students are likely to remember this only when in the first year. By the time they finish their undergraduate university education conformity to authoritative modes of teaching and learning could result in the loss of skills and knowledge gained during LKA dialogic sessions. Dialogic pedagogical innovation requires liberatory teaching and learning whereby Archer (2010) morphogenetic cycle is applied in university lecture spaces.

\section{CONCLUSION}

It can be concluded that through an appropriately designed dialogical pedagogy students can be empowered to transform the structural constraints to their education and create enablers that can help them succeed in their learning. There is evidence that within the LKA pedagogical architecture the students have the opportunity to take responsibility for their learning and thus are enabled to exercise agency. The study recommends that LKA should be developed into a core curriculum that is offered beyond first year level so as to achieve the best results through the programme. How then can LKA inform faculties to embrace an emancipator and collaborative space for good citizenship to manifest itself in university spaces/classrooms? 
In sum: This article draws attention to the importance of student voice(s) as co-creators of knowledge and understanding when innovative dialogic pedagogy forms an integral part of higher education institutions in the $21^{\text {st }}$ century.

\section{REFERENCES}

Alexander, R. 2004. Towards dialogic teaching: Rethinking classroom talk. Cambridge: Dialogos.

Alexander, R. 2006. Towards dialogic teaching: Rethinking classroom talk. York: Dialogos U.K Ltd.

Alexander, R. 2010. Dialogic teaching essentials. Cambridge: Cambridge University Press.

Archer, M. 1995. Realist social theory: The Morphogenetic approach. Cambridge: Cambridge University Press.

Archer, M. 2010. "Morphogenesis versus structuration: On combining structure and action". British Journal of Sociology 61: 225-252.

Archer, M. 2010. "Morphogenesis versus structuration: On combining structure and action." British Journal of Sociology (33)(4) (Dec., 1982): 455-483. https://www.jstor.org/stable/pdf/589357 (Accessed 19 September 2018).

Bakhtin, M. M. 1981. The dialogic imagination: Four essays, ed. M. Holquist. Translated by M. Holquist and C. Emerson. Austin: University of Texas Press.

Bakhtin, M. M. (Ed.). 1984. Problems of Dostoevsky's poetics. Translated by M. M. Bakhtin. Caryl Emerson. Minneapolis: University of Minnesota Press.

Becker, S. and A. Bryman. 2004. Understanding research for policy and practice. Bristol: Policy Press.

Cook, V. 1991. Second language learning and language teaching. London: Edward Arnold.

Denzin, N. and Y. S. Lincoln. (Eds.). 2003. Introduction: The discipline and practice of qualitative research. In The landscape of qualitative research, ed. N. Denzin and Y. Lincoln. Theories and Issues: 1-45.

Flecha, R. 2000. Sharing words: Theory and practice of dialogic learning. Lanham, MA: Rowman and Littlefield Publishers, Inc.

Freire, P. 1970. Pedagogy of the oppressed. New York: The Continuum Publishing Company.

Freire, P. 2005. Teachers as cultural workers. Letters to those who dare teach. Boulder, CO: Westview press.

Gibbons, T. and G. Sanderson. 2002. Contemporary themes in the Research Enterprise. International Education Journal 3(4): 1-22.

Gómez, A., S. Racionero and T. Sordé. 2010. Ten years of critical communicative methodology. International Review of Qualitative Research 3(1): 17-44.

Gray, D. E. 2005. Doing research in the real world. London: Sage publications Ltd.

Gumede, M. 2017. Pan-Africanism is going strong: Ngugi wa Thiong'o focuses on decolonising language. https://www.businesslive.co.za/bd/opinion/2017-03-08-ngugi-wa-thiongo-focuses-ondecolonising-language/ (Accessed 15 March 2017).

Maybin, J. 2003. The potential contribution of linguistic ethnography to Vygotskian studies of talk and learning in school. Paper presented at the UKLEF Colloquium at BAAL Annual Meeting, 4-6 September 2003, University of Leeds: Linguistic Ethnography at the Interface with Education.

Mcleod, S. 2007. Vygotsky: Simply Psychology. https://www.simplypsychology.org/vygotsky.html (Accessed 15 December 2013).

Mcleod, S. (Updated 2018). Vygotsky: Simply Psychology. https://www.simplypsychology.org/ vygotsky.html (Accessed 19 September 2018).

Mercer, N. 2000. Words and minds: How we use language to think together. London: Routledge. 
Mouton, J. 1996. Understanding social research. Cape Town: Van Schaik Publishers.

Nesari, A. J. 2015. Dialogism versus monologism: A Bakhtinian approach to teaching. Elsevier Ltd. Procedia - Social and Behavioral Sciences 205(2015): 642-647.

Nystrand, M., A. Gamoran, R. Kachur and C. Prendergast. 1997. Opening dialogue: Understanding the dynamics of language and learning in the English classroom. New York: Teachers College Press.

Padrós, M., R. Garcia, R. Mello and S. Paul. 2011. Contrasting scientific knowledge with knowledge from the lifeworld: The dialogic inclusion contract. Qualitative Inquiry 17: 304. DOI: 10.1177/1077800410397809.

Paul, R. and L. Elder. 2008. The miniature guide to critical thinking concepts and tools. Foundation for Critical Thinking Press.

Presseisen, B. and A. Kozulin. 1992. Mediated learning - The contributions of Vygotsky and Feuerstein in theory and practice. A paper presented at the Annual Meeting of the American Educational Research Association, San Francisco, California.

Rautopuro, J. and P. Vaisanen. 2001. Non-traditional students at university: A follow-up study of young and adult students' orientations, satisfaction and learning outcomes. Paper presented at the European Conference on Educational Research: Lille.

Rule, P. 2011. Bakhtin and Freire: Dialogue, dialectic and boundary learning. Educational Philosophy and Theory 43(9): 924-942.

Shor, I. and P. Freire. 1987. What is the "dialogical method" of teaching? Journal of Education 169(3): 11-31.

Skidmore, D. 2000. From pedagogical dialogue to dialogical pedagogy. Language and Education 14(4): 283-296.

Tochon, F. V. 1998. Bakhatinian plagiarism in group interactctions: From negative interdependence semiotic model to constructive learning. Paper presented at the annual meeting of the American Educational Research Association (AERA), Santiego, CA, April 1998. ERIC Document ED 418959.

University of Fort Hare. 2011. Life, knowledge, action: The Grounding Programme at the University of Fort Hare.

University of Fort Hare. 2016. Life, knowledge, action: The Grounding Programme at the University of Fort Hare. 